\title{
Gêneros do Jornalismo e técnicas de entrevista
}

\author{
Pedro Celso Campos
}

\section{Resumo}

O que é mais importante: informar, divertir, opinar ou interpretar, quando se trata de escrever o texto jornalístico? Qual a importância de subdividir o jornalismo em gêneros? Que outros recursos podem ajudar o jornalista no encaminhamento da sua reportagem? Estes assuntos interessam diretamente aos estudantes de jornalismo, desde que a preocupação maior seja a busca da qualidade na prática profissional. Do contrário, não fazem sentido. Todavia, ter consciência dos gêneros - até mesmo pela divisão do espaço físico do jornal - pode ser útil naqueles momentos em que o repórter pode voar mais alto, sobrepondo os gêneros, assumindo o chamado "texto de autor", conduzindo o receptor através de uma leitura agradável, fascinante, com emoção, em que tudo se funde na concretude de um texto maior. Ali o repórter não esconde a sua opinião, pode ser lúdico na narrativa, passará informações de qualidade e interpretará o fato com maestria, contextualizando, explicando, esclarecendo.

Palauras-chave:

Jornalismo, Gêneros, Ética, Qualidade, Serviço

\section{Genres in Journalism and interviewing techniques}

\section{Abstract}

\section{Sobre $\bullet$ autor}

Doutor pela Escola de Comunicação e Artes da Universidade de São Paulo (ECA-USP), com pós-doutorado na Universidade de Sevilha, é professor na Faculdade de Arquitetura, Artes e Comunicação (FAAC) da Universidade Estadual Paulista "Júlio de Mesquita Filho" - UNESP, campus de Bauru. pcampos@faac.unesp.br
What is more important: Inform, Entertain, Judge or Interpret, concerning the writing of a journalistic text? What is the purpose of subdividing journalistic discourse in genres? What other resources might help the journalist in the construction of the news article? These subjects directly interest the students of Journalism, though providing the major concern be the seeking of quality while exercising the profession. Otherwise, they are meaningless. Nevertheless, being aware of such genres - even for the division of physical space within the press office - might be useful in those moments in which the reporter can fly higher, breaking through the genres, adopting the designated "author's text", thus leading the receptor through a more joyful, fascinating, passionate reading, in which everything melds together in the concreteness of a greater text. There, the reporter shall not hide his opinion, shall be able to be playful in the narrative, will pass dependable information and will interpret the fact with consummate skill, placing it in a context, explaining and making it clear.

Key words:

Journalism, Genres, Quality, Professional Ethics, Service 


\section{Informativo}

A questão dos gêneros na práxis informativa ainda é uma área muito polêmica. Entretanto faz-se necessário estabelecer uma classificação de tendências em que a informação se processa (cf. Medina, 1988: 55). Pelo menos no impresso, ao abrir um jornal, por exemplo, o leitor mais atento perceberá o predomínio de artigos assinados e matérias claramente opinativas como o Editorial. Nas páginas seguintes terá notícias curtas e algumas reportagens mais extensas. No caderno final e nos suplementos especializados terá uma informação mais amena, até com uma linguagem mais alegre como na crônica esportiva ou nas crônicas propriamente ditas. Há ainda reportagens fartamente ilustradas sobre viagens, saúde, lazer, comportamento, literatura, além de palavras cruzadas, tiras, horóscopo, adivinhações etc. Por isto alguns autores ${ }^{1}$ classificam as matérias jornalísticas por seu conteúdo Informativo (as notícias curtas), Opinativo (os editoriais e colunas assinadas), Interpretativo (os textos mais explicativos, que interpretam o fato através de reportagens e entrevistas contextualizadas) e Recreativo (mais voltado para o lazer e a diversão do leitor).

Cremilda Medina entende que o Gênero Recreativo não é uma terminologia adequada, tendo em vista as transformações que os jornais estão experimentando com as novas tecnologias e com as pesquisas $^{2}$ que identificam a adequada segmentação de público à qual correspondem os conteúdos de cada gênero. Ao fim e ao cabo, o que os jornais e toda a mídia buscam é alcançar a maior audiência possível porque é isto que atrai anunciantes e melhora o faturamento publicitário. Esse interesse pelo aspecto econômico-financeiro que permeia, de fato, todo o processo de produção capitalista voltado para a acumulação ${ }^{3}$, está suficientemente resumido no título da obra clássica de Medina: Notícia - Um produto à venda (1988).

Neste artigo vamos tentar caracterizar um pouco melhor cada um desses quatro gêneros do jornalismo. De início vale ressaltar que qualquer gênero é, antes de tudo, Informativo, pois a notícia é a matéria-prima do jornalismo. "Que vem a ser essa figura tão importante, espécie de prima donna da imprensa, vedete insubstituível no domínio jornalístico?", indaga Luiz Amaral (1997: 39). E responde com múltiplas definições: "Notícia é algo que você não sabia antes". "É um pedaço do social que volta ao social". "É tudo que o público necessita saber, tudo que o público deseja falar". Ela se torna tanto mais significativa e interessante em função de sua atualidade (imediatismo), proximidade (local), importância (valor intrínseco), transmissibilidade (clareza), conflito (polêmica), suspense (capacidade de prender a atenção), emoções (presença do ser humano) e conseqüências (tendência futura).
${ }^{1}$ Para Todorov (apud Manuel Carlos Chaparro, M.C., em Sotaques D'Aquém e D'Além Mar - Percursos e Gêneros do Jornalismo Português e Brasileiro. Portugal: Jortejo, 1998: 117), "gêneros são classes de textos com propriedades comuns". Assim, outros autores reúnem os textos jornalísticos mais de acordo com a forma que o conteúdo: entrevistas, reportagens, artigos, colunas, editoriais, pequenas notas etc.

${ }^{2}$ Em palestra sobre "Novos Paradigmas da Ciência”, na Unesp, campus de Bauru, por ocasião da Semana Nacional de Ciência e Tecnologia, em 5 out. 2005, a psicóloga e doutora em filosofia pela UFRJ, Viviane Mosé, produtora do quadro do Fantástico (TV Globo), revelou que a emissora carioca - líder de audiência no país - faz pesquisas permanentemente para verificar as demandas do gosto popular, com o objetivo de não investir em gêneros e produtos de pouca aceitação. No caso do quadro sobre os grandes filósofos - "Ser ou não Ser - a pesquisa de opinião pública constatou, segundo ela, que as pessoas estão interessadas em formação, e não apenas em informação.

3"As flores do campo e as paisagens têm um grave defeito: são gratuitas. $\mathrm{O}$ amor à natureza não estimula a atividade de nenhuma fábrica", afirma o Diretor de Incubação e Condicionamento em Admirável Mundo Novo, de Aldous Huxley, 1981: 20. 
Encontramos no registro de Amaral (id.: 42) a grande lição que o jornalismo deveria observar, sempre, quando produz notícia: "Um acontecimento só nos detém quando, de uma forma ou de outra, temos a impressão de participação ou identificação... para ser compreendido pelo público o repórter deve partir daquilo que ele conhece bem - ele próprio - e falar a linguagem do coração". O mestre está nos ensinando a não abrir mão da emoção, a colocar-nos no lugar do outro, a sentir a sua dor ou o seu prazer, suas angústias, suas alegrias. Para tanto "é preciso descobrir na notícia um ponto de interesse, de contato, uma brecha que sirva para atrair o espírito do leitor" (id., ibid.). Geralmente o leitor se interessa por assuntos relacionados com sexo, morte, destino, dinheiro, situação do tempo, atos de generosidade e a piedade presente nos casos absurdos e emocionantes. Para Pierre Lévy (1998:55), "notícia é a virtualização do fato através do real simbólico".

\section{Recreativo}

Como vimos, o recreativo é uma forma ainda mais discutível de classificar os gêneros do jornalismo. Como relacionar na categoria de "recreativa" uma matéria de comportamento que trata de situações extremas diante das doenças graves ou terminais ou mesmo da própria morte? A reportagem sobre descobertas científicas pode ser definida como recreativa? E as matérias sobre Educação? O que outros autores defendem - como Alberto Dines - é um estilo leve, bem humorado, mais arejado, que não deve ficar confinado a este ou aquele caderno, mas que deve perpassar todo o jornal, do Esporte ao Editorial. A este respeito, o jornalista Márcio Moreira Alves (apud Amaral, 1978: 140) critica a linguagem rígida dos editoriais brasileiros que, na sua opinião, parecem querer atingir a cabeça do leitor como uma pedrada, tentando enfiar-lhes goela abaixo a persuasão imaginada pelo editorialista.

De qualquer forma - com esta ou aquela classificação - o jornalismo precisa dar atenção ao leitor que busca um pouco de lazer, de recreação, de divertimento, algo para passar o tempo, descompromissadamente. A cultura do lazer é uma presença crescente no estressante ritmo da vida atual predominantemente urbana. Antigamente condenado como "preguiça", hoje o ócio com dignidade é visto como hábito saudável, sinal de inteligência emocional, traço cultural e sócio-econômico, como define Domenico De Masi. Isto significa que os jornais e toda a mídia devem valorizar o noticiário sobre cultura, esporte, teatro, cinema, viagens, humor, as crônicas e sátiras, o humor em geral... a própria educação ambiental pode ser passada, com excelentes resultados, através da informação lúdica, dos jogos em forma de infográficos, dos desenhos e tiras, das histórias em quadrinhos, das crônicas etc. ${ }^{4}$

4"Os momentos escolhidos para ler os jornais são os intervalos de repouso: o descanso que segue ao almoço, a espera do jantar ou a hora de dormir. [...] a leitura dos jornais é a distração conscientemente procurada, nas salas de espera, nos (domingos e) feriados, quando chove", afirma Jean Stoetzel ao relacionar a recreação como a segunda função psicossocial da imprensa (após a função de atualização), acrescentando que o próprio público considera a leitura dos jornais como uma atividade de prazer. Ao mesmo tempo, para Jean-Jacques ServanSchreiber, em O Desafio Americano, "uma das principais características da civilização pós-industrial é o número de horas de lazer, cada vez maior, que o homem poderá desfrutar". Cf. Amaral, 1978: 20-21. 


\section{Opinativo}

Mas o jornalismo não tem apenas o dever de informar e divertir - mesmo quando educa. Também tem o direito e o dever de opinar. É com a opinião segura, abalizada, bem fundamentada, que o veículo de comunicação cumpre seu papel social a serviço do receptor, agindo com transparência, passando seriedade e credibilidade. É necessário que os jornalistas tenham liberdade para comentar a realidade, orientando seus leitores. Infelizmente, entretanto, não é sempre assim, nem mesmo em países mais desenvolvidos. Basta lembrar o sensacionalismo dos tablóides ingleses ou a demissão do jornalista Peter Arnett, em 2004, nos EUA, por ter criticado a invasão do Iraque. É o que nos leva a constatar, infelizmente, que não existe liberdade de imprensa, apenas liberdade de empresa. Por isto muitos jornalistas se acomodam, como denuncia Ignacio Ramonet, do Le Monde Diplomatique, aceitando as regras do mercado e silenciando quando deviam se manifestar. Para Luiz Beltrão (1980: 14), é a opinião que

valoriza e engrandece a atividade do jornalista, pois quando expressa com honestidade e dignidade, com a reta intenção de orientar o leitor, sem tergiversar ou violentar a sacralidade das ocorrências, se torna fator importante na opção da comunidade pelo mais seguro caminho à obtenção do bem-estar e da harmonia social.

No que se refere especificamente ao Jornalismo Ambiental, o "dever de opinar" é igualmente sagrado, pois trata-se de informar claramente sobre situações que aparentemente são vantajosas para a sociedade mas que escondem ciladas e intenções não reveladas pelos interesses ideológicos em jogo. Mas para opinar é preciso conhecer, estudar, pesquisar, checar dados, confrontar fontes, "gastar sola de sapato" como se diz. É isto que faz o diferencial entre os bons e os maus jornalistas, entre os que têm garra e os que têm preguiça, entre os que são céticos e os que acatam tudo... qual jornalista se lembrou de pesquisar melhor quando, décadas atrás, um laboratório lançou o medicamento Talidomida para uso na gravidez? Mas todos noticiaram, anos mais tarde, o nascimento de crianças com defeitos físicos em todo o país...

\section{Interpretativo}

Aparentemente o gênero Interpretativo - cuja base é a investigação acurada - confunde-se com o Opinativo. Mas não se trata da mesma coisa. Enquanto o Opinativo parte da informação ou de um pressuposto que configura uma hipótese a ser provada, desenvolvendo em seguida uma argumentação lógica baseada em boa pesquisa, terminando com uma conclusão persuasiva, o Interpretativo deixa para o leitor a decisão de acatar ou não a informação 
passada do modo mais claro e mais explicativo possível, sempre buscando a contextualização histórica, o entorno do fato, os detalhes do acontecido ou declarado, para ir além do meramente declaratório. Advoga-se, na verdade, um jornalismo que possa mostrar ao leitor as tendências futuras, isto é, o encaminhamento que o fato pode tomar, mas não a partir de futurologia irresponsável, e sim de um relacionamento "ótimo" com as fontes do setor. O relacionamento com a fonte é ótimo quando a cumplicidade profissional preserva a ética e o respeito mútuo, quando o profissional preserva o nome da fonte nas declarações em off e quando nem um nem outra usam o jornalismo com outro propósito que não o de levar a informação verdadeira ao público alvo. Naturalmente o bom repórter sabe que é necessário checar as informações e também sabe que não existem dois lados na notícia, mas muitos lados, talvez alguns conflitantes. Por isto é necessário checar, conferir, confrontar dados, ouvir de novo as mesmas fontes, se necessário.

Este é, talvez, o gênero mais difícil - talvez por isto o mais gratificante - do jornalismo, porque exige ainda mais apuração, mais entrevistas, mais consultas, mais investigação, mais envolvimento da equipe para que o trabalho saia "redondo", na expressão de Alberto Dines ${ }^{5}$, para que o leitor receba todas as informações relacionadas com aquele tema e possa tirar, com segurança, suas próprias conclusões.

Entretanto, é neste gênero que se destacam os grandes jornalistas. Basta lembrar que foi com a ferramenta do Interpretativo que surgiu o New Journalism, nos Estados Unidos, com destaque para os textos da revista Time, em 1923, que inaugurou um estilo mais explicativo para noticiar os fatos da semana, influenciando o surgimento de publicações semelhantes como The New Yorker (celeiro dos primeiros livros-reportagem como A Sangue Frio, de Truman Capote; O Segredo de Joe Gould, de Joseph Mitchell etc), L'Express, na França; Der Spiegel, na Alemanha; $L ' E u r o p e o$, na Itália etc. Grandes nomes se revelaram no gênero interpretativo como John Reed, Tom Wolfe, Norman Mailer, Ernest Hemingway, Gay Talese, Gabriel García Márquez e também o herói nacional de Cuba, José Martí, entre outros.

No Brasil esse modo de fazer jornalismo de qualidade apareceu em 1928, na revista O Cruzeiro, de Assis Chateaubriand, registrando seu auge nos anos 50, com os memoráveis textos de David Nasser, Joel Silveira, Edmar Morel e tantos outros. Mas foi em 1951, com a reforma do Diário Carioca, onde Pompeu de Souza introduziu pela primeira vez na imprensa brasileira a técnica americana do lead e o Manual de Redação - como forma de sistematizar e padronizar a produção de notícias - que teve início a fase moderna da imprensa brasileira, já a essa altura operando em moldes empresariais.

${ }^{5}$ Alberto Dines (1986: 91) lembra, entretanto, que "o gênero investigativo foi sendo abandonado, aos poucos, pela imprensa brasileira, justamente quando os grandes jornais preferiram a linha 'empresarial', que consiste basicamente em informar sem se comprometer. $\mathrm{O}$ golpe fatal lhe foi desferido paradoxalmente quando a 'febre' da comunicação e do seu controle invadiu as instituições brasileiras [na década de 1970]. Organismos privados ou públicos passaram a organizar seus departamentos de informações para filtrar e divulgar através de notas e releases, a matéria de seu interesse ou que lhes era solicitada". 
Outro passo importante na melhoria de qualidade do nosso jornalismo foi a reforma do Jornal do Brasil, por Alberto Dines, que trouxe da imprensa americana a idéia do Caderno de Pesquisa e do Caderno Especial de Domingo, em que os profissionais poderiam escrever textos mais amenos e contextualizados, interpretando a realidade. Uma Realidade que surgiu como revista mensal em 1966 (preservando as características originais de narrativa diferenciada até 1968 ), ícone da imprensa brasileira, consolidando em nosso país o "Novo Jornalismo", juntamente com o Jornal da Tarde, em São Paulo, também em 1966, dando asas à imaginação criadora de nomes como José Hamilton Ribeiro, Luiz Fernando Mercadante, Domingos Meirelles, Joel Silveira, Mauro Santayana e tantos outros, que Audálio Dantas reuniu no livro Repórteres, em 1997, com apoio da Editora Senac.

O "Jornalismo de Autor" - como Dines chamava o "Novo Jornalismo brasileiro" - também teve seu espaço na fase pioneira da revista Veja, seguindo-se, depois, os livros-reportagem de Fernando Morais, Zuenir Ventura, Ruy Castro, Caco Barcelos e os estudos acadêmicos na área do Jornalismo Literário (como veremos a seguir) com o professor Edvaldo Pereira Lima (ECAUSP) e Celso Falaschi (PUC-Campinas) criadores do site www. textovivo.com.br.

Hoje o texto interpretativo está desprestigiado, embora já se observe uma tendência à sua retomada, diante do "cansaço" provocado pelo excesso de informações curtas e superficiais que os meios despejam sobre o receptor sem apresentar qualquer diferencial. O que tem ocorrido, infelizmente, é que a mesma tecnologia que situou o jornalismo como uma atividade de ponta na indústria gráfica do país, empurra os meios de comunicação para a necessidade de disputar mercado através da multiplicidade de pequenas notícias, abordando todos os assuntos, porém de forma superficial e meramente quantitativa. Parte-se do princípio que o apressado leitor de nossos dias não tem tempo para "saborear" longas reportagens. Por isso as empresas não investem mais em coberturas de fôlego, preferindo reduzir custos com a produção de notícias curtas que muitas vezes chegam pelas agências de notícias, dispensando a contratação de jornalistas. Quando o jornal é regional, a cobertura local fica praticamente entregue a interesses políticos e empresariais. Mesmo parte expressiva do noticiário ambiental é "importada" de regiões distantes, como se no "local" não existissem problemas ambientais. Assim, não há interpretação da realidade e o jornalismo perde sua vocação principal, que não é disputar espaço com os meios eletrônicos, mas fazer o aprofundamento, a contextualização que o fato exige.

A este respeito, afirma Ulisses Capozolli, presidente da Associação Brasileira de Jornalismo Científico:

\section{interpretativo está desprestigiado, embora já se observe uma tendência à sua retomada, diante do "cansaço" provocado pelo excesso de informações curtas e superficiais}


A imprensa tem pela frente um enorme desafio: o de fazer jornalismo interpretativo, ou seja, de contextualização histórica dos acontecimentos como esforço para oferecer uma inteligibilidade possível do mundo. Essa deve ser a alternativa, ao menos para a imprensa escrita, de enfrentar o caos informativo trazido pela Internet. Essa é a nova função da imprensa, resultado do impacto não só da tecnologia, mas do que se poderia chamar, novamente, de "novos tempos".

Alguns observadores da mídia chegam a afirmar que o espaço para o jornalismo interpretativo, de qualidade, já está de volta, em parte da mídia, e que em muitas redações o que falta mesmo é profissional com a necessária sensibilidade, a indispensável força de vontade e a natural capacidade de escrever bem para relançar o gênero. A se confirmarem tais prognósticos, caberá, naturalmente, à escola preparar profissionais mais criativos, menos propensos aos bitolamentos tradicionais da objetividade racionalista que teima em ter sempre a bordo os instrumentos inibidores da criatividade que são a apuração apressada, o excessivo formalismo do lead, os rigores do Manual da Redação, a pauta fechada (que não dá abertura de abordagem ao repórter) etc.

Com a flexibilização curricular aprovada pelo Ministério da Educação e Cultura em 1996 e regulamentada em 2002, os cursos de jornalismo já têm liberdade para montar currículos mais adaptados às caraterísticas sociais, culturais e econômicas de cada região do país, o que abre perspectivas para currículos mais compreensivos em relação às demandas sociais da atualidade. Novos métodos de ensino centralizados no aluno, nos quais o professor é mais uma instância de aprendizado, e não a única, com a necessária implosão das paredes que cercam a sala de aula - através do uso adequado da internet, ferramenta que revolucionou profissões como as dos comunicadores - permitem à área acadêmica proporcionar um ensino em sintonia com os "novos tempos" de que fala Capozolli.

Algumas escolas do país - poucas ainda - estão introduzindo a disciplina Jornalismo Ambiental na graduação, na pós-graduação e também nas especializações. Esta é uma disciplina que oferece a oportunidade de levar o aluno ao questionamento da sociedade e dos modelos econômicos vigentes, despertando nele o senso crítico inerente ao profissional que se destaca do lugar comum. Afinal, trata-se de uma matéria intensamente interdisciplinar, que abarca várias áreas do conhecimento (economia, antropologia, sociologia, política etc) e que pode servir de modelo para a preparação de futuros jornalistas com visão ampliada na análise da complexidade do mundo. Este esforço de estudo interdisciplinar é próprio da característica sistêmica que envolve o conceito de meio ambiente permanentemente aberto em sua multiplicidade de abordagens e métodos. Para Edgar Morin (2003: 16),
A disciplina

Jornalismo

Ambiental oferece

a oportunidade de levar o aluno ao questionamento da sociedade e dos modelos econômicos vigentes 
[...] devemos, pois, pensar o problema do ensino, considerando, por um lado, os efeitos cada vez mais graves da compartimentação dos saberes e da incapacidade de articulá-los, uns aos outros; por outro lado, considerando que a aptidão para contextualizar e integrar é uma qualidade fundamental da mente humana, que precisa ser desenvolvida, e não atrofiada.

Por isso, sendo o foco deste trabalho a tentativa de encontrar novos formatos, novas linguagens, novos paradigmas de informação e de formação jornalística, optamos por tratar o estudo do jornalismo ambiental através de uma nova abordagem que alia o honesto registro do fato acontecido (ou da declaração), como é esperado do jornalismo, com a capacidade de ousar na criatividade, na imaginação, na descrição de detalhes, na imersão em profundidade, no registro de histórias de vida das pessoas do mundo real (e não só dos "olimpianos" - termo que tomamos emprestado de Cremilda Medina - e autoridades).

Estamos falando de uma nova linguagem jornalística, uma ferramenta que pode mudar o modo de fazer jornal. É a proposta do Jornalismo Literário Avançado.

\section{Jornalismo Literário Avançado}

A abordagem do Jornalismo Literário Avançado nasceu na Escola de Comunicação e Artes - ECA, da Universidade de São Paulo, a partir da tese de doutoramento do seu criador, professor Edvaldo Pereira Lima, na década de 1990. Trata-se de um aperfeiçoamento da disciplina Jornalismo Literário, que é ensinada na Europa e nos EUA, constituindo-se, com a sua adaptação ao Brasil, uma significativa contribuição acadêmica para a retomada do "jornalismo da totalidade" amparado na Teoria Geral dos Sistemas.

A principal característica desse método é, exatamente, o rompimento com o paradigma linear presente no reducionismo de filiação iluminista-cartesiana. Valoriza a capacidade de observar a realidade com outros olhos, literalmente com "os olhos da mente", abrindo espaço para o lado direito do cérebro que é mais abrangente e subjetivo. Com este método o jornalista poderá ver a floresta além da árvore, ou atingirá a percepção diferencial de não ver apenas o dedo quando lhe apontarem as estrelas. Aquela pauta que renderá uma simples entrevista para o jornalista convencionalmente lógico, poderá significar um saboroso perfil para outro menos apressado, porque toda pessoa humana tem uma história e, para Edvaldo, "não existe história ruim, o que existe é história mal contada". Isto também vale para as instituições, as cidades, os lugares. Nada nem ninguém está isolado ou perdido no mundo. Buscar esses elos de interconexão do ser, aparentemente individual, no Ser cósmico, relevar a plenitude da vida, sua jornada, suas transformações, seus pontos de virada, sua trajetória, seus altos e baixos, suas glórias e misérias..é isto que faz o Jornalismo Literário Avançado, seja através do livro-reportagem, do flash-book, do perfil ou mesmo do texto curto.
Aquela pauta que renderá uma simples entrevista para o jornalista convencionalmente lógico, poderá significar um saboroso perfil para outro menos apressado, porque toda pessoa humana tem uma história 
Dessa forma, enquanto a mediação convencional transforma uma entrevista em informações, as técnicas de "imersão" ou de "observação participante" darão ao jornalista filiado ao JLA a oportunidade de transmitir idéias, o que é absolutamente singular se aceitarmos que a mente humana pensa a partir de idéias e não de informações, como nos lembra Roszak ${ }^{6}$. Por isto o JLA recomenda a História de Vida em substituição à doutrinação quando o objetivo é a persuasão. Vimos isso lá atrás, em Agostinho e Francisco, que pregavam através de exemplos. Para Capra (1994: 69) "todo conhecimento significativo é conhecimento contextual, e grande parte dele é vivencial e tácita". Por outro lado, para transmitir a "vivência" do outro, é necessário que o próprio jornalista se faça "outro", de tal modo a passar para o receptor não a narrativa da experiência, mas a experiência em si que agora já será como que "sua" experiência, por estar incorporado nela. A este respeito, afirma Pereira Lima (1995: 258-259):

\begin{abstract}
Na visão holística do mundo, o observador não pode ter uma leitura correta da realidade se não se preparar, ele próprio, para a condição necessária à nova perspectiva de entendimento. Observador, observado e a coisa observada transformam-se em interação sistêmica, crescem para novos níveis de compreensão. Só assim, mediante a experiência própria, o jornalista terá capacidade de despertar, no leitor, os estados de percepção similares aos que vivenciou.
\end{abstract}

Todavia, "descobrir o outro, revelá-lo para os outros reivindica renúncia e coragem. Desvestir-se das crenças pessoais, das histórias de classe e família, da fama efêmera, do sucesso com o chefe circunstancial, das facilidades momentâneas e, literalmente, como se dizia há alguns anos, 'pisar no barro', é um salto no escuro”, como adverte Cremilda Medina (2003: 149). E acrescenta:

\begin{abstract}
São várias etapas. Abrir-se, aprender a ouvir, a respeitar o diverso, a lidar com os desiguais, a ser descrente e apurar, a recuperar visões distintas, a eleger o pequeno como parte essencial do todo e a odos tratar igualmente. Porque nessa tarefa o que eqüivale é a humanidade. E a informação bem trabalhada é patrimônio da humanidade. Seja entre as mulheres afegãs, as africanas esterilizadas, as nordestinas famintas e malcuidadas, as modelos tornadas objetos de consumo ou os senhores de todos os poderes.
\end{abstract}

Contar boas histórias. Contá-las bem. Com emoção. Este é o grande diferencial para a narrativa jornalística dos "novos tempos". Mas se agir friamente e apressadamente, se não se preparar, o jornalista não alcançará a empatia que Erasmo de Rotterdam (2005: 69-70) ensinava:
6"A informação é apresentada como a base do pensamento, enquanto que, na realidade, a mente humana pensa com idéias e não com informações. [...] Idéias são padrões integrativos que não derivam da informação, mas sim da experiência." Cf. Theodore Roszak. In The Cult of Information. Apud Capra, 1996: 69. 
O homem é feito de maneira que as ficções lhe causam muito mais impressão que a verdade. Quereis uma prova clara e sensível? Ide a vossas igrejas quando lá se prega. Se o orador trata de algum assunto sério, as pessoas se aborrecem, bocejam, dormem; mas se, mudando subitamente de tom e de assunto, [...] o pregador põe-se a recitar com ênfase alguma velha história popular, a audiência logo muda de atitude: todos despertam, se aprumam, escutam, todos são olhos e ouvidos.

Contudo, se a característica da narrativa pelo JLA é o rompimento do lead racionalista, para deixar passar todas as influências benéficas do nosso campo morfogenético, é preciso lembrar, com clareza, que a narrativa sempre parte do fato real acontecido, vez que o JLA trabalha com a literatura da realidade. $\mathrm{O}$ que faz toda diferença é que no JLA a pauta é totalmente flexível e a captação não é apressada, do mesmo modo que a narrativa não está estrangulada pelo arcabouço das pirâmides invertidas, do lead, do sub-lead, do dead-line imediato etc.

Já nos primeiros anos da faculdade, os estudantes de jornalismo que pretendem se aprofundar na opção pelo JLA para escreverem suas reportagens experimentais ou seus trabalhos de conclusão de curso, geralmente preferem a "cabeça bem-feita" à "cabeça bem cheia" de que fala Montaigne, explicado por Edgar Morin (2003: 21).

O significado de uma cabeça bem cheia (grifo nosso) é óbvio: é uma cabeça onde o saber é acumulado, empilhado, e não dispõe de um princípio de seleção e organização que lhe dê sentido. Uma cabeça bem-feita (grifo nosso.) significa que, em vez de acumular o saber, é mais importante dispor ao mesmo tempo de uma aptidão geral para colocar e tratar os problemas [e dispor, igualmente, de]... princípios organizadores que permitam ligar os saberes e lhes dar sentido.

Normalmente esses alunos pesquisam as novas ciências, como as Ciências da Terra (entre elas a Geografia), a Cosmologia (que trata do Universo), a Ecologia (que trata dos ecossistemas), a História das Civilizações (aprendendo mais sobre Islã, China, Índia), a Psicologia Arquetípica de Jung ${ }^{7}$, a Teoria dos Campos Morfogenéticos ampliada por Rupert Sheldrake ${ }^{8}$, a mitologia moderna estudada por Joseph Campbell ${ }^{9}$ etc. Sobre a importância de estudar os mitos, e até mesmo o próprio sonho, Campbell dirá: "Uma coisa que se revela nos mitos é que, no fundo do abismo, desponta a voz da salvação. O momento crucial é aquele em que a verdadeira mensagem de transformação está prestes a surgir. No momento mais sombrio surge a luz".

Eles igualmente lêem livros de Fritjof Capra, onde aprendem sobre a complexidade da vida e a abordagem holística, ou de Amit Goswami, sobre física quântica, isto é, sobre as ligações possíveis entre ciên-
${ }^{7}$ Jung rompeu com Freud por discordar, dentre outras teses, que o subconsciente humano tivesse uma natureza predominantemente sexual. Jung considerava, além do inconsciente individual, o inconsciente coletivo, constituído por símbolos universais, transmitidos de geração em geração e cristalizados nos arquétipos, como a anima, que é a faceta feminina da personalidade masculina, e o animus, que é a faceta masculina da personalidade feminina [...]. Os arquétipos, enquanto patrimônio comum a toda a humanidade, podem ser encontrados na literatura, na arte, e em outros produtos culturais. No indivíduo, eles se manifestam nos sonhos e constituem fatores determinantes da personalidade e da conduta. Em Jung a terapia para os males psicológicos está na busca do equilíbrio. Exemplos de arquétipos do inconsciente coletivo são o mito do paraíso perdido, a figura do velho sábio, o herói etc. Cf. Encilopédia Tudo. São Paulo: Abril Cultural, [s.d.]: 131 e 748.

${ }^{8} \mathrm{~A}$ Teoria dos Campos Morfogenéticos trata da determinação, da visualização e da projeção mental que podem solucionar problemas aparentemente incontornáveis, segundo Pereira Lima (1995: 255). Rupert Sheldrake é autor de O Renascimento da Natureza e de Os Sete Experimentos que Podem Mudar o Mundo", publicados pela Cultrix, São Paulo.

${ }^{9}$ Os estudos de Campbell sobre mitologia moderna influenciaram grandes criadores do cinema mundial como Spielberg e Lucas. A citação referida está em $O$ Poder do Mito, 1990: 39. 
cia e espiritualidade, ou sobre o grande mestre do pensamento complexo que é Edgar Morin. Na verdade, esses alunos identificados com as técnicas do JLA estudam a abordagem sistêmica do saber, como em Bertalanfy, assim analisada por Morin. (op. cit.: 26):

\begin{abstract}
A Teoria Geral dos Sistemas - que parte do fato de que a maior parte [sic] dos objetos da física, da astronomia, da biologia, da sociologia, átomos, moléculas, células, organismos, sociedades, astros, galáxias formam sistemas, ou seja, conjuntos de partes diversas que constituem um todo organizado - retomou a idéia, freqüentemente formulada no passado, de que um todo é mais que o conjunto das partes que o compõem...[...] assim as propriedades do ser vivo são desconhecidas na medida de seus constituintes moleculares isolados, elas emergem neste e para esta organização. A rotina, fruto da ciência disciplinar, era tão forte que, por muito tempo, o pensamento sistêmico permaneceu afastado das ciências, tanto naturais como humanas, e, ainda hoje, é marginalizado.
\end{abstract}

Não faltaria assunto para tratar do JLA ao longo de todo este trabalho se este fosse nosso único propósito. Mas o que buscamos aqui é apresentar as "ferramentas do sistema", isto é, alguns recursos que os futuros jornalistas poderão utilizar na proposta de um outro jornalismo possível, voltado para a leitura totalizante da realidade. Como o JLA, em sua metodologia, contempla exatamente este modo de ver, e como o estudo do meio ambiente apresenta características igualmente interdisciplinares por excelência, entendemos que o JLA pode ser uma boa ferramenta de trabalho. Sendo assim, podemos penetrar, agora - tendo adquirido, com humildade, o saber dos mentores - em algumas minúcias da própria técnica do fazer jornalístico que tem, na entrevista, sua matéria prima, etapa determinante nesta nossa jornada em busca do Graal do saber. Um saber que não nos torna melhores nem mais felizes se não colocado a serviço de uma finalidade nobre como é levar às pessoas um conhecimento integrado, inclusivo, holístico, que é muito mais do que simples informação, para não incorrermos na dúvida de T. S. Eliot (apud Morin, 2003: 17): "Onde está o saber que perdemos na informação? Onde está a sabedoria que perdemos no conhecimento?"

\section{Técnicas de entrevista}

Algumas técnicas são essenciais na entrevista para o JLA, destacando-se, como já foi dito, o aspecto da "imersão". Nas histórias de vida, antes de mais nada, é preciso conquistar a simpatia do entrevistado. E isto não se faz com meias-verdades, com mentiras, com falsa identidade, com câmaras ocultas ou com qualquer outro expediente escuso. Pelo contrário, para estabelecer uma
Nas histórias de vida, antes de mais nada, é preciso conquistar a simpatia do entrevistado. $E$ isto não se faz com meias-verdades com qualquer outro expediente escuso 
boa interação com a fonte, o jornalista deve ser honesto, transparente, amigo, companheiro. Ninguém abre a caixa preta da vida, na sua intimidade mais crua e mais exposta, a uma pessoa não confiável, estranha, maquiavélica. Por outro lado, o próprio jornalista deve se precaver para não se envolver em situações ilegais. Em depoimento à imprensa, no início de 2003, sobre seu livro a respeito de um traficante, Caco Barcellos contou que estabeleceu algumas normas, segundo as quais não tomaria conhecimento - durante as entrevistas - de fatos criminosos em andamento ou futuros, apenas de fatos passados. Também é necessário obter, logo de início, um documento assinado em que o entrevistado autoriza a divulgação de texto e imagem a seu respeito, o que poderá livrar o profissional de futuros e caros processos por uso indevido de imagem.

Uma vez conquistada a simpatia do entrevistado, é necessário passar a conviver com ele em seu próprio ambiente. Foi assim que Joseph Mitchell escreveu uma das mais bonitas reportagens, em meados do séc. XX, contando a história de um boêmio do Greenwich Village, em Nova York, o popular Joe Gould, que estaria escrevendo uma História Oral maior que a Bíblia. Mitchell sempre evitava os lugares-comuns do jornalismo: celebridades, poderosos, "olimpianos"... Seus personagens viviam à sombra, anônimos. Suas reportagens eram buriladas anos a fio e foram elas que melhor capturaram o espírito de Nova York entre as décadas de 30 e 60 . O primeiro perfil de Gould foi publicado na revista The New Yorker no fim de 1942. Em 1964, Mitchell completaria o perfil de Gould, sete anos após a morte de seu personagem, com o qual conviveu longamente nos bares da cidade até "percebê-lo" nos mínimos detalhes.

Não agiu diferente outro destacado jornalista-literário norteamericano, Norman Mailer, ao descrever "a luta do século" entre Cassius Clay (Muhamed Ali) e George Foreman, realizada em 1974, no Zaire. O autor entrou "em comunhão" com seu personagem, interagindo com ele, sentindo suas dores, experimentando suas alegrias, participando de corridas com ele, convivendo em sua casa, no Zaire, tornando-se quase uma "extensão" da pessoa. Afinal, essa luta tinha algo de ideológico entre o americanismo escancarado de Foreman e o muçulmanismo combativo de Clay, aquela coisa de Bem contra o Mal tão própria do judaísmo-cristão e tão cara aos que continuam se achando no direito de mapear o "eixo do mal" sobre a terra.

O polêmico Truman Capote passou seis anos fazendo entrevistas, coletando dados, lendo documentos, pesquisando, até publicar, em 1965, o clássico $A$ sangue frio [sic], por ele considerado o primeiro livro-reportagem com recursos literários, baseado em fato real, narrando um crime ocorrido em 1959 no interior do Kansas, no meio-oeste americano. Para uma verdadeira "imersão" no
Ninguém abre a caixa preta da vida, na sua intimidade mais crua e mais exposta, a uma pessoa não confiável, estranha, maquiavélica 
contexto dos fatos, o autor mudou-se - por um ano - para a cidadezinha de Holcomb, onde um casal e seus dois filhos foram assassinados friamente, numa tragédia que causou comoção nacional.

Ao posfaciar o relançamento de A sangue frio [sic], pela Editora Companhia das Letras, em 2003, Matinas Suzuki Jr. baseouse em longa entrevista concedida pelo próprio Capote a George Plimpton, publicada em 16 de janeiro de 1966, em The New York Times, para expor o método de apuração que o autor utilizou até chegar ao que batizou de "romance de não-ficção". As informações que Suzuki Jr. coletou no referido depoimento revelam que

\footnotetext{
Capote entrevistou por longo tempo um grande número de pessoas sem fazer anotações ou gravá-las. Segundo ele, a anotação e a gravação prejudicam o tempo dedicado à observação dos personagens e do ambiente, e intimidam os entrevistados, que perdem a naturalidade e deixam de fazer revelações importantes. Gay Talese, outro expoente do jornalismo literário, também condena o uso de gravador e das anotações na frente do entrevistado. Capote dizia ter treinado com um amigo uma técnica de prestar atenção absoluta ao que ouvia (o amigo lia longos trechos de um livro em voz alta, e depois Capote, qual um "fotógrafo literário", tentava reproduzir literalmente o trecho lido). Ele gabava-se de conseguir cerca de 95\% de total precisão.
}

A citação literal do texto tem o objetivo de lançar luz sobre a já referida dúvida que muitos profissionais têm na hora de registrar a apuração. Entretanto, mais do que a expressão mecânica do método - gravar ou anotar ou um dos dois ou nem um nem outro, o que resulta bastante relativo conforme as situações profissionais que se apresentam ou conforme as capacidades e limitações de cada entrevistador - o mais importante é reter o conceito do método. Trata-se, com efeito, de exigir do entrevistador uma concentração especialíssima sobre o que está ouvindo, uma capacidade de percepção do real muito superior ao que normalmente chamamos de "prestar atenção". Não basta prestar atenção, é preciso "entrar" na história, pensar junto com o entrevistado, "copiar" o seu vôo, como se diz no jargão da aviação quando o piloto precisa repetir, em vôo, as manobras do colega ou da equipe, como faz a Esquadrilha da Fumaça.

A segurança da manobra depende literalmente dessa capacidade de interação do piloto com o grupo, numa fusão quase perfeita entre homem e máquina, tal como conta Edvaldo Pereira Lima (1995: 94) a respeito de Ayrton Senna ao conquistar suas melhores marcas com pneus de chuva, exatamente quando os concorrentes não conseguiam a concentração suficiente para evitar as fatídicas derrapagens. Muitos fazem entrevistas, muitos se põem a fazer perguntas durante dias a fio a um personagem determinado para escrever uma "história de vida". Mas poucos se perguntam por que Mitchell, Capote e todos os ases do jornalismo literário eram tão cuidadosos
Trata-se, com efeito, de exigir do entrevistador uma concentração especialíssima sobre o que está ouvindo, uma capacidade de percepção do real muito superior ao que normalmente chamamos de "prestar atenção" 
na apuração e levavam tanto tempo para produzir o relato. Tudo bem que contavam com o apoio (inclusive, ou principalmente, financeiro, coisa que falta hoje em dia) do fundador da revista The New Yorker, Harold Ross, e do editor Willian Shawn, que financiaram os dois autores e publicaram seus livros, inicialmente, em capítulos.

$\mathrm{Na}$ verdade, resolvido o problema financeiro, não se pode ter pressa para produzir o jornalismo literário. Este é um gênero em que não basta registrar os fatos, é preciso pensar a narrativa, rechecar informações, conferir dados, ficar atento ao andamento da situação. No caso de $A$ sangue frio, por exemplo, a obra pareceria incompleta ou menos importante sem a solução final representada pela execução dos criminosos. Seria transformar uma tragédia de grande repercussão em conto da carochinha, parodiando os clássicos dos irmãos Grimm: "E ficaram presos para sempre". Também Mitchell só revelou o segredo do seu personagem depois que Joe Gould morreu.

Além dessas técnicas de entrevista, de narrativa, dos gêneros etc, o jornalista conta com a valiosa ferramenta da fotografia para valorizar suas reportagens. A fotografia dá vida ao texto, atrai a atenção do receptor, ajuda a explicar e contextualizar as situações. Por isto o fotojornalismo é disciplina obrigatória no curso superior, compondo-se de parte teórica e parte laboratorial. Na cobertura ambiental, a fotografia exerce um destacado papel de documentação e de referência. Entretanto, como a notícia ambiental ainda não merece da imprensa convencional a devida valorização, não é raro o uso de fotos meramente "ilustrativas" nas matérias ambientais, isto é, fotos retiradas de arquivo, portanto sem a presença participante do fotógrafo no local dos fatos, de tal modo que a matéria passa uma informação, mas a foto transmite outro contexto que o editor, arbitrariamente, superpõe. Em outras situações a foto é "tratada" para "dar conta" de explicar o fato. Ainda há casos em que a foto de arquivo é publicada sem crédito e sem data, de modo a dificultar o entendimento do receptor. No âmbito da fotografia são muitos os atentados à ética da informação, enquanto se imagina estar preservando a estética da diagramação à custa do sumário sacrifício da verdade.

\section{Conclusão}

Podemos concluir, afinal, que o jornalista dispõe de várias ferramentas como suporte à produção do texto de qualidade. Além dos atributos próprios de seu estilo, de sua verve, de sua capacidade intelectual e, sobretudo, de sua capacidade de apuração da notícia, ele pode conceber o texto - ainda na fase mental - direcionando-o para a técnica estritamente informativa; ou para o entretenimento; ou para a persuasão ou, então, para o aprofundamento interpretativo, neste caso explicando melhor a informação, contextualizando-a com o antes, o agora e o depois. Também pode usar as técnicas de entrevista, lembrando-se que cada caso é um caso e que não há receita pronta. Conta muito, neste
Como a notícia ambiental ainda não merece da imprensa convencional a devida valorização, não é raro o uso de fotos meramente "ilustrativas" nas matérias ambientais 
caso, a acuidade da observação do que se passa em volta ou mesmo no semblante, na mente ou no coração do entrevistado. Por isto é importante preferir o contato pessoal que a entrevista a distância. Há ainda o acervo de ferramentas oferecidas pelo Jornalismo Literário Avançado. Na verdade o jornalista precisa ter não apenas competência mas também um pouco de sorte para estar na empresa certa no momento exato. A maleabilidade da empresa que aceita desafios editoriais joga a favor do bom repórter naquelas horas decisivas em que o grande fato não manda recado nem avisa que está chegando. Em outras situações, com editores que se sentem pouco à vontade para romper paradigmas e bancar "aventuras" (como fez o editor do Washington Post no caso Watergate nos anos 1970) então é doloroso ser criativo e às vezes não resta outra opção senão pegar o boné e ir batalhar um espaço profissional em cidade maior ou em veículo mais aberto. $\mathrm{O}$ fundamental é jamais abrir mão dos ideais e de um jornalismo criativo, ético, sério e totalmente voltado para o serviço ao receptor. Este é o melhor de todos os gêneros: o jornalismo de serviço.

\section{Referências}

AMARAL, L. Jornalismo: Matéria de Primeira Página. Rio de Janeiro: Tempo Brasileiro, 1997.

. Técnica de Jornal e Periódico. Rio de Janeiro: Tempo Brasileiro, 1978.

BELTRÃO, L. Jornalismo Opinativo. Porto Alegre: Sulina, 1980.

CAMPBELL, J. O Poder do Mito. São Paulo: Palas Athena, 1990.

CAPRA, F. A Teia da Vida - Uma Nova Compreensão Científica dos Sistemas Vivos. Trad. de Nilton R. Eichemberg. São Paulo: Cultrix, 1996.

DINES, A. O Papel do Jornal. São Paulo: Summus, 1986.

LÉVY, P. O que é Virtual?. Trad. de Paulo Naves. São Paulo: Editora 34, 1998.

LIMA, E. P. Ayrton Senna, Guerreiro de Aquário. São Paulo: Brasiliense, 1995.

LIMA, E. P. Páginas Ampliadas - O Livro-Reportagem como extensão do jornalismo e da literatura. $4^{\text {a }}$ ed. São Paulo: Manole, 2009.

MEDINA, C. Notícia, um produto à venda. São Paulo: Summus, 1988.

. Entrevista, o diálogo possível. São Paulo: Ática, 1990.

. A Arte de Tecer o Presente. Narrativa e Cotidiano. São Paulo: Summus, 2003.

MORIN, E. A Cabeça bem feita. 8 ed. Trad. de Eloá Jacobina. São Paulo: Bertrand Brasil, 2003.

ROTTERDAM, E. Elogio da Loucura. 2005.

VILAS BOAS, S. Perfis - Como escrevê-los. São Paulo: Summus, 2003. 